\title{
Cytotoxic and Antiproliferative Effects of Methanolic Extract of Lavandula Angustifolia on MCF-7 Breast Cancer Cell Line
}

\author{
Mitra Javanmardi ${ }^{1}$, Mohammad-Karim Khosropanah ${ }^{2}$, Mohammad-Nazir Menbari ${ }^{3}$, Nikoo Darvishi ${ }^{4}$, \\ Sabrieh Amini ${ }^{5}$, Nahid Haghnazari ${ }^{6}$, Mohammad Abdi ${ }^{7,8}$ \\ 1. Ph.D. Candidate, Department of Biology, Sanandaj Branch, Islamic Azad University, Sanandaj, Iran. ORCID ID: 0000- \\ 0002-3854-5191 \\ 2. Assistant Professor, Department of Biology, Sanandaj Branch, Islamic Azad University, Sanandaj, Iran., (Corresponding \\ Author), Tel: 087-33288661, Email: khosropanah.mk@iausdj.ac.ir. ORCID ID: 0000-0003-2683-1585 \\ 3. Assistant Professor, Cellular and Molecular Research Center, Research Institute for Health Development, Kurdistan \\ University of Medical Sciences, Sanandaj, Iran. ORCID ID: 0000-0001-8668-2281 \\ 4. Assistant Professor, Cellular and Molecular Research Center, Research Institute for Health Development, Kurdistan \\ University of Medical Sciences, Sanandaj, Iran. ORCID ID: 0000-0002-9132-9164 \\ 5. Assistant Professor, Department of Biology, Sanandaj Branch, Islamic Azad University, Sanandaj, Iran. ORCID ID: 0000- \\ 0002-9978-5455 \\ 6. Assistant Professor, Department of Biology, Sanandaj Branch, Islamic Azad University, Sanandaj, Iran. ORCID ID: 0000- \\ $0002-4717-5153$ \\ 7. Associate Professor, Cellular and Molecular Research Center, Research Institute for Health Development, Kurdistan \\ University of Medical Sciences, Sanandaj, Iran. ORCID ID: 0000-0002-4766-0423 \\ 8. Associate Professor, Department of Clinical Biochemistry, Faculty of Medicine, Kurdistan University of Medical \\ Sciences, Sanandaj, Iran., (Corresponding Author), Tel: 087-33664674, E-mail: abdi@muk.ac.ir. ORCID ID: 0000-0002- \\ 4766-0423
}

\begin{abstract}
Background and Aim: In recent years, special attention has been paid to the use of complementary drugs in the treatment of breast cancer. Previous studies have shown that lavender (Lavandula angustifolia) has antiproliferative properties. In the present study, the possible antiproliferative effects of methanolic extract of lavender in MCF-7 breast cancer cell line were investigated.

Materials and Methods: In this experimental study, MCF-7 breast cancer cell line was treated with different concentrations of methanol extract of lavender. Cell survival was assessed using MTT assay. The cell cycle was analyzed using flow cytometry. The ability of breast cancer cells to form a colony after treatment with plant extract was also investigated. The main components of the methanol extract were identified by GC/MS method. The T-test, ANOVA and Tukey statistical methods were used for data analysis.

Results: The results showed that the methanolic extract has significant cytotoxicity on MCF-7 cells, the G0/G1 phase arrest after treatment with methanolic extract in the breast cancer cell line increased significantly. The main contents of the MetOH extract were determined as Coumarin $(59.44 \%)$, Tricosane (15.22\%), 7-methoxy Coumarin (12.69\%), and 2-Furancarboxaldehyde (6.7\%).

Conclusion: In conclusion, according to the results of this study, the lavender methanolic extract has a cytotoxic effect on MCF-7 cells; therefore, lavender can be considered as a potential therapeutic supplement in future studies of breast cancer.
\end{abstract}

Keywords: Cytotoxicity, Breast cancer, Lavandula angustifolia, Methanolic extract, MCF-7

Received: Nov 8, $2020 \quad$ Accepted: Dec 1, 2020

How to cite the article: Mitra Javanmardi, Mohammad-Karim Khosropanah, Mohammad-Nazir Menbari, Nikoo Darvishi, Sabrieh Amini, Nahid Haghnazari, Mohammad Abdi. Cytotoxic and Antiproliferative Effects of Methanolic Extract of Lavandula Angustifolia on MCF-7 Breast Cancer Cell Line. SJKU. 2021;26(1):86-97.

Copyright $\odot 2018$ the Author (s). Published by Kurdistan University of Medical Sciences. This is an open access article distributed under the terms of the Creative Commons Attribution-Non Commercial License 4.0 (CCBYNC), where it is permissible to download, share, remix, transform, and buildup the work provided it is properly cited. The work cannot be used commercially without permission from the journal 


\section{اثرات سميت سلولى و ضد تكثيرى عصاره متانولى اسطوخودوس (Lavandula angustifolia) روى ردهى سلولى MCF-7 سرطان يستان}

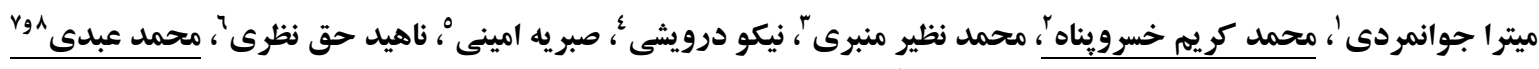

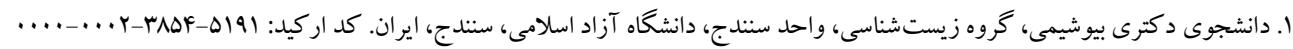

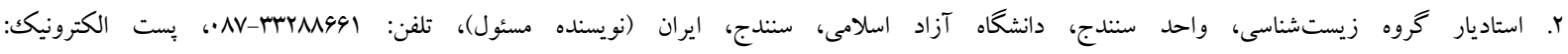

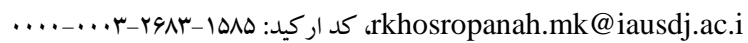

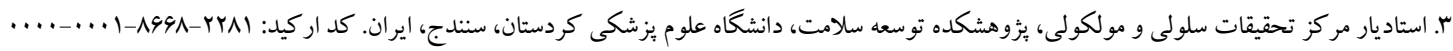

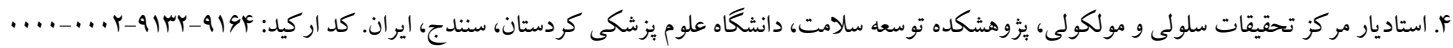

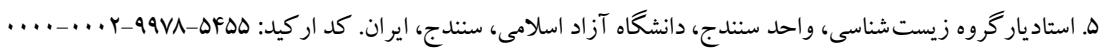

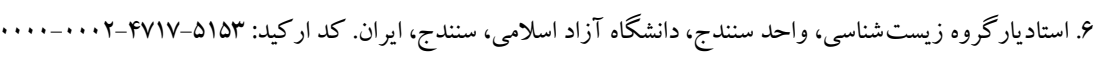

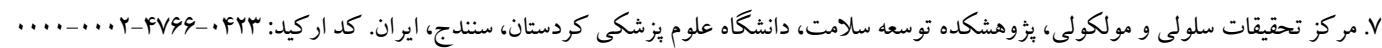

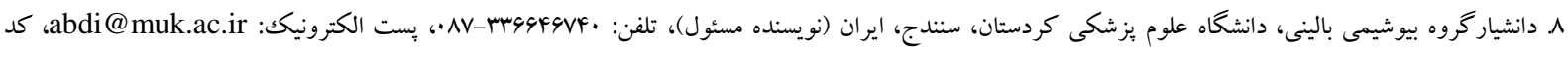

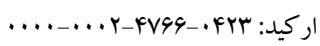

جكيuه زمينه و هدف: در سالهاى اخير توجه ويزّاى به استفاده از داروهاى مكمل در درمان سرطان بستان شده است. در مطالعات

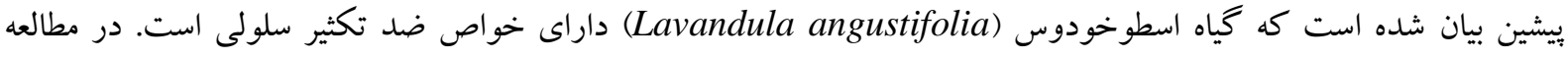

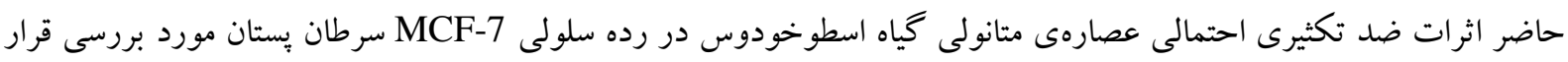

مواد و روشها: در اين مطالعه تجربى، رده سلولى MCF-7 سرطان بِّتان با غلظتهاى مختلف عصارهى متانولى گياه

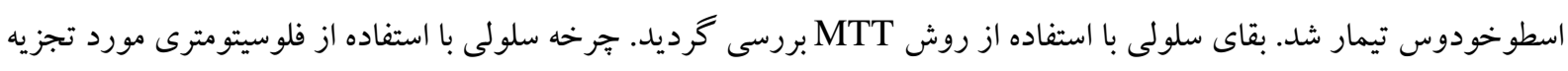

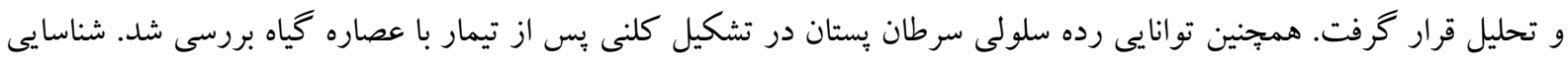

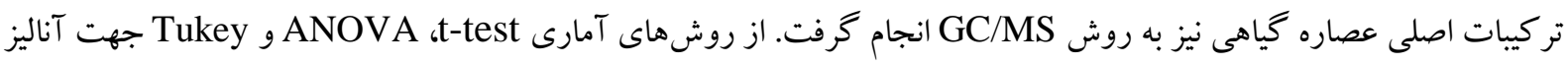
نتايج استفاده شد.

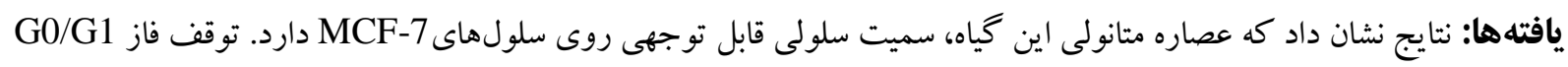

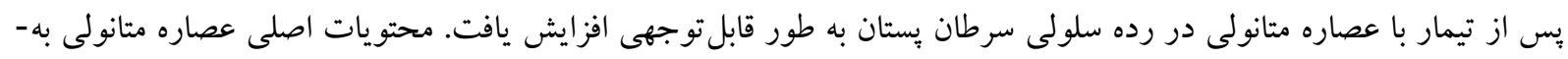

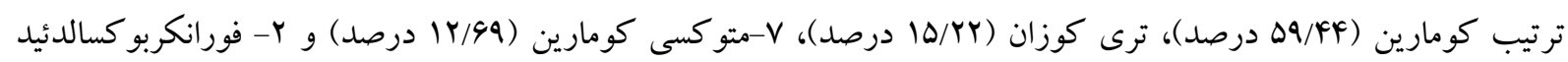

(9/V) نتيجه كيرى: در مجموع، بر اساس نتايج اين تحقيق، عصاره متانولى اسطوخودوس روى سلولهاى MCF-7 اثر سميت سلولى

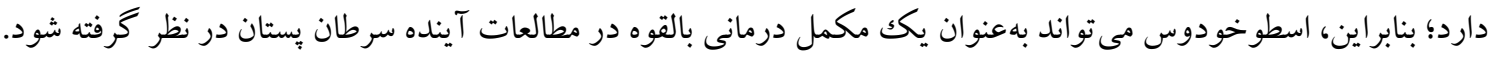
وازه هاى كليدى: سميت سلولى، سرطان بستان، اسطوخودوس، عصاره متانولى، MCF-7 وصول مقاله:99/N/1 اصلاحيه نهايى:99/9/9 يذيرش: 
إيى -a-كادينول و Z-فيتول هستند، در حالى كه عصاره انهگزانى عمدتاً حاوى اوی-سينئول، كافور و بورنئول

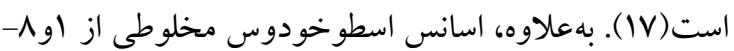

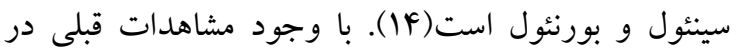
مورد خو اص سيتوتو كسيك گياه اسطوخودوس، نتايج بسيار

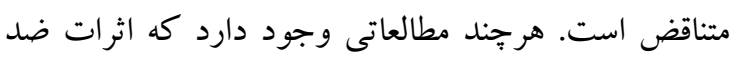

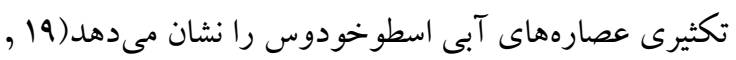

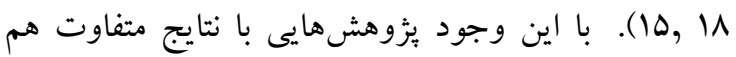
گزارش شده است(19). همجنين در مطالعه اى ديخر مشخص شده است كه عصاره اتانولى اين گياه نيز توانايى

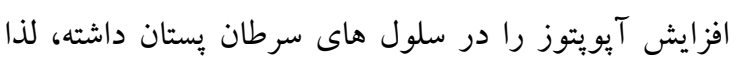
سبب مهار رشد اين نوع از سلولهاى سرطانى مى شود (IV).

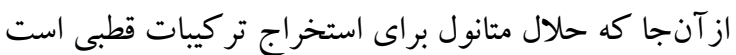

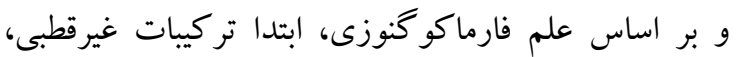

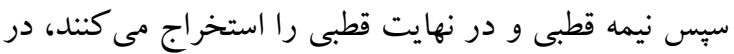
اين مطالعه، تركيبات غيرقطبى و نيمه قطبى بهترتيب با نا

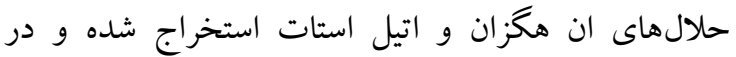
نهايت با استفاده از حلال متانول تركيبات قطبى جدا سازى

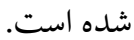

L. angustifolia بلوجه به اينكه اثرات سميت سلولى روى سلولهاى سرطانى پيتان بهخوبى درك نشده است، بهعلاوه اينكه اثر عصاره متانولى اين گياه روى اين دسته از سلولهاى سرطانى تاكنون مورد مطالعه قرار نخرفته است، بنابر اين در اين مطالعه، خواص سيتوتو كسيك و ضد تكثيرى عصارهى متانولى اسطوخودوس بر رده سلولى MCF-7 سرطان بِتان بررسى گرديد.

\section{مواد و روشها} تهيه عصاره اسطوخودوس اندام هوايى اسطوخودوس از نمونهاى كشت شده در كلخانه دانشكده كشاورزى دانشگاه آزاد واحد سنندج، درد

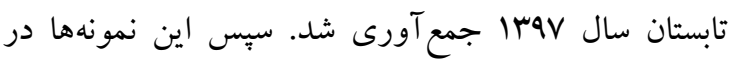

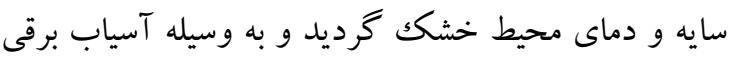

\section{مقدمه}

سرطان بِّتان بهعنوان شايع ترين سرطان در بين زنان در نظر

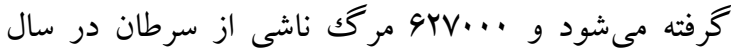
Y.1N در سراسر جهان را تشكيل مىدهد. ميزان شيوع بررسى شده بر اساس سن سرطان پستان در ايران // I...... سرطان پِتان شامل شيمى درمانى، جراحى، راديوترابى، هورمون درمانى و درمان هدفمند است. با اين وجوده،

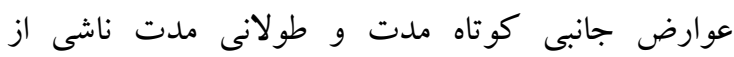
مداخلات درمانى مانند يائسخى، نابارورى زودرس، اختلال

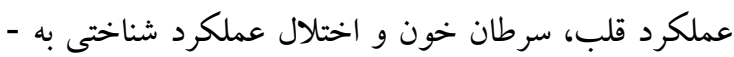

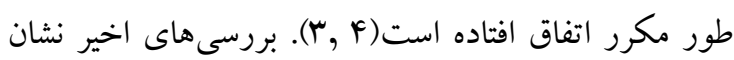

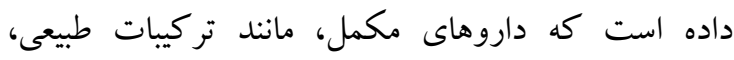
مىتواند در بسيارى از بيماران سرطانى با حداقل عوارض جانبى، درمان را بهبود ببخشند(V-V). اسطوخودوس (Lavandula angustifolia) از خياهان خانو اده نعناع بوده و بومى غرب مد مديترانه مى باشد. از مدتهاتها

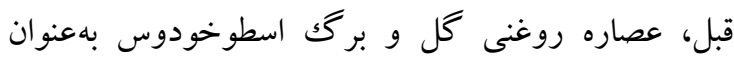

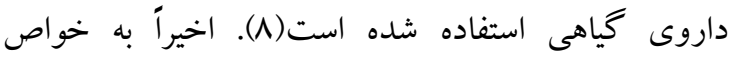
سيتو تو كسيك عصارههاى اسطوخودوس توجه بيشترى شده و فعاليتهاى ضد باكتريايى، آنتىاكسيدانى و ضد سرطانى اين عصارهها در بسيارى از مطالعات كزارش شده است( 1. 9, (9). علاوه بر اين، عصاره اسطوخودوس خواص درمانى را در برابر بيمارىهاى روماتيسمى(II)، اختلالات عصبى(Ir)

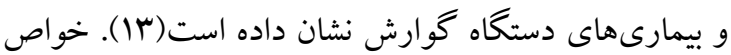
ضد تومورى عصاره آبى اسطوخودوس نيز روى سرطان يروستات (F) (1)، ردههاى سلولى MCF-7 و HeLa نشان داده

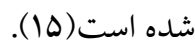

عصاره آبى اسطوخودوس عمدتاً حاوى لينالول (9؟\% تا

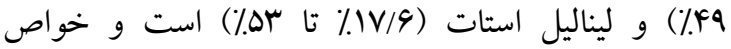
درمانى گياه به اين تركيبات نسبت داده شده است(19). در مقابل، اجزاى اصلى عصاره اتانولى شامل اوی-سينئول، 
متانول تيمار شد كه بهعنوان كنترل حلال از آنها استفاده

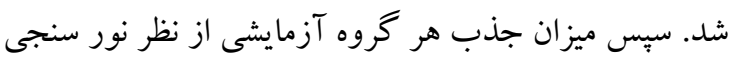

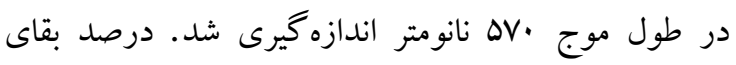
سلولى با فرمول زير محاسبه شد:

OD treated/OD control $\times 100$ آناليز جرخه سلولى: رده سلولى MCF-7 را در بِليت 9 جاهكى كشت داده شد شد

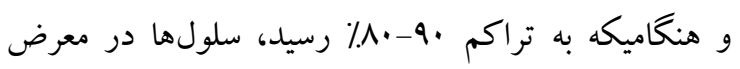
محيط كشت تيمار قرارگرفتند. به اين ترتيب كه ابتدا

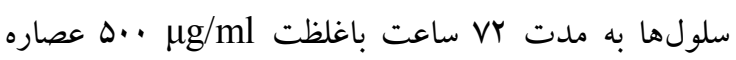

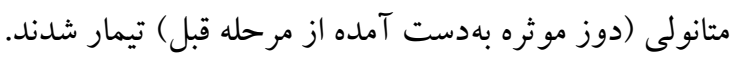
همين روش براى گروههاى كنترل سلول و كنترل حلال نيز

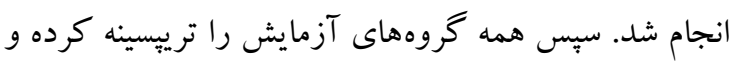
يس از جداشدن سلولها از كف يليت با دور

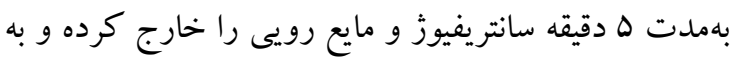

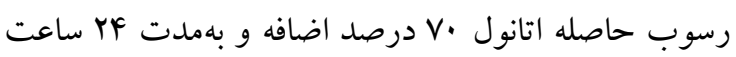

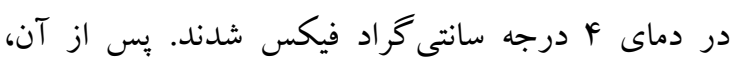
سلولهاى فيكس شده بار ديخر با دور

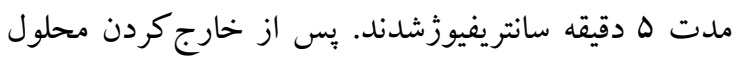

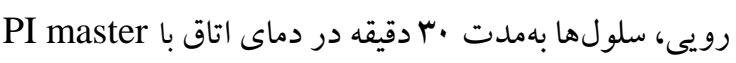

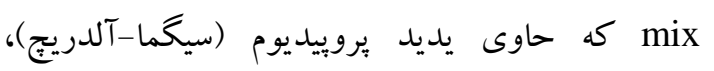
PBS و RNase سلولى از دستخاه فلوسيتومتر BD FACScalibur flow cytometer (BD Biosciences, Mountain View, FlowJo استفاده كرديد. از نسخه Y, CA) • ا نرم افزار CA)

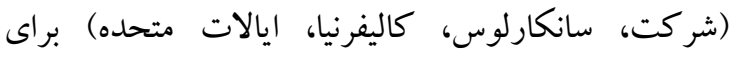
ارزيابى ميزان سلولهاى موجود در مراحل مختلف جرخه سلولى استفاده شد.

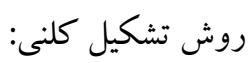

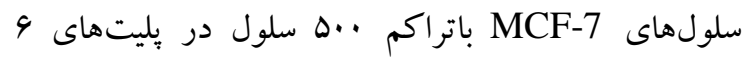
جاهكى با استفاده از r ميلى ليتر محيط كشت، كشت داده

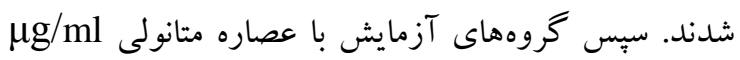

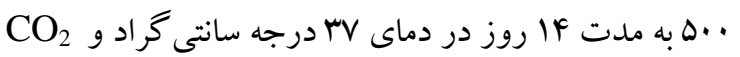

بهصورت يودر درآمد. عصارهى متانولى اسطوخودوس با

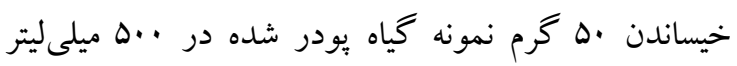
متانول خالص و در مدت FN ساعت تهيه شد. عصاره

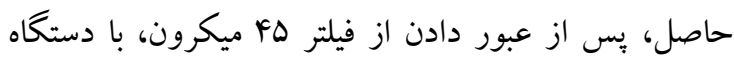

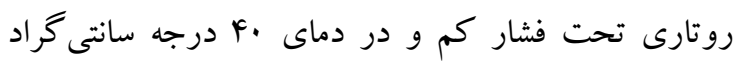

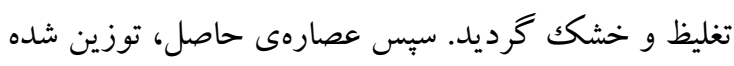

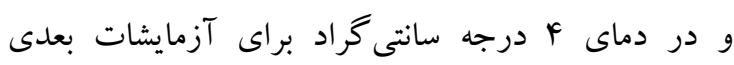
نغهدارى شد. آمادهسازى نمونه ها:

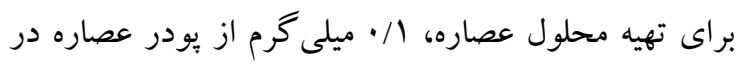

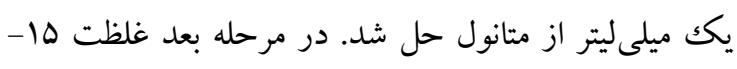

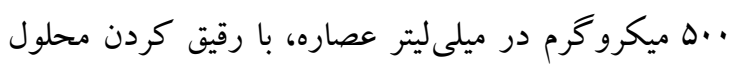

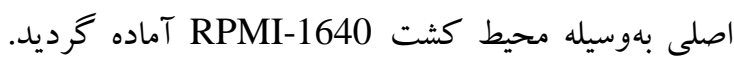
محلولهاى مذكور قبل از هر آزمايش بلصورت تازه تهيه

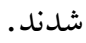

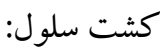
در اين مطالعه رده سلولى MCF-7 سرطانى پِّتان از مركز بين المللى مهندسى زنتيك و وبيوتكنولوزى (ICGEB)

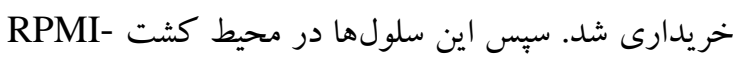
1640 حاوى FBS ده درصد، ينى سيلين، استريتومايسين و

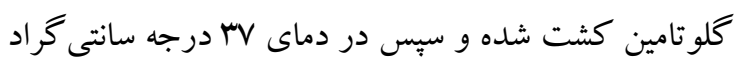
و بنج سنجش تكثير سلولى:

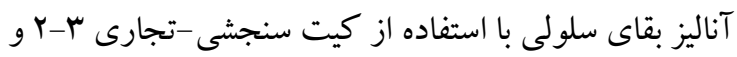

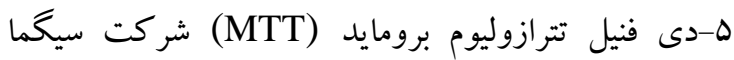

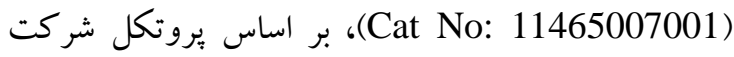
سازنده بررسى گرديد. به اين ترتيب كه ردهى سلولى

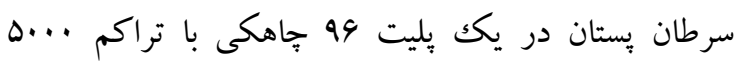

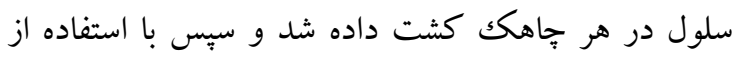
غلظتهاى مختلف عصارهى متانول (15-500 (بg/mL)

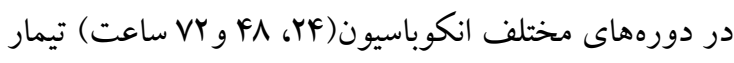

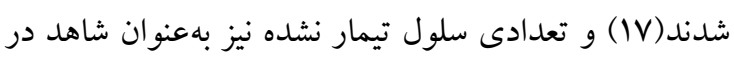

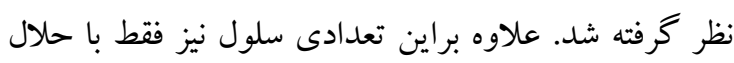


مربوطه براى هر تركيب با محاسبه درصد سطح زير منحنى بهدست آمد.

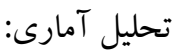
تجزيه و تحليل دادهها با استفاده از نرمافزار SPSS نسخه

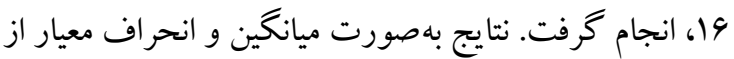

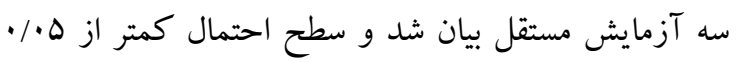

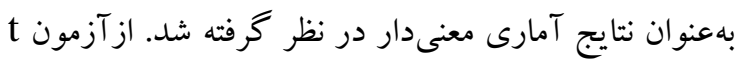

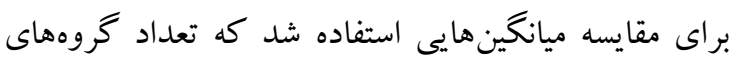

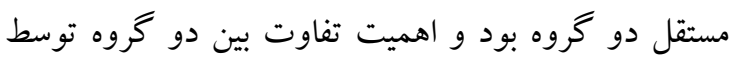

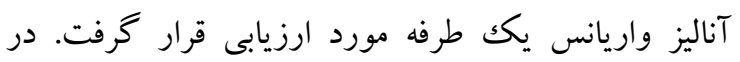
مواردى كه نتايج ANOVA يككطرفه قابل توجه بود، از آزمون تعقيب TukeyHSD براى تشخيص تفاوت درون

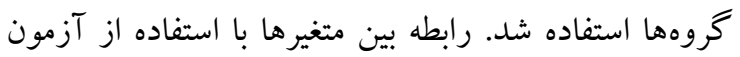

$$
\text { همبستخى اسبيرمن بررسى شد. }
$$

\section{يافتهها}

$$
\text { تر كيب شيميايى عصاره: }
$$

بررسى تركيبات اصلى به روش GC/MS نشان داد كه عصارهى متانولى اسطوخودوس در مجموع از ^ تر كيب فرار تشكيل شده است. در نهايت محتواى اصلى عصاره متانولى

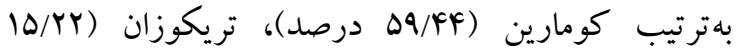
درصد)، V-متو كسى كومارين (Y/99 درصد) و Y-فوران كربو كسالدئيد (9/V درصد) تعيين شد. تركيبات شيميايى عصاره و مقدار آنها در عصارههاى مختلف در جدول 1
ينج درصد تحت تيمار قرار گرفتند. سبس سلولها با PBS شسته شده و با حلال متانول إr اسيد استيك تثبيت شدند. سلولهاى ثابت بهمدت •F دقيقه باكريستال ويوله \&/. درصد رنگكآميزى شدند. كلنىهاى رنغك آميزى شده در

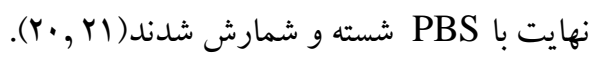
تعيين تركيبات موجود در عصاره متانولى اسطوخودوس به

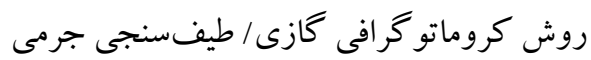

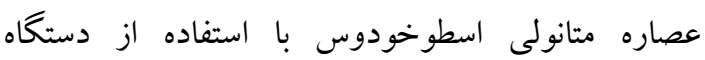
GC/MS

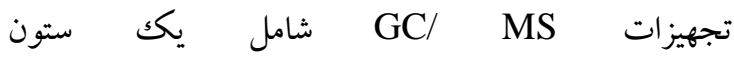

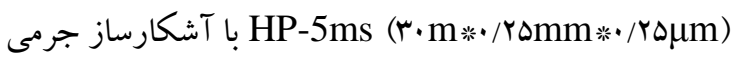
جهار قطبى بود. دادهها توسط رايانه اى مجهز به كتابخانه Wiley بهدست آمده و يُردازش شدند. شرايط جداسازى دابه

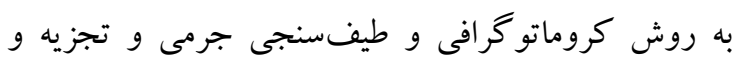
تحليل به اين شرح بود كه دماى آون •9 درجه سانتى كراد

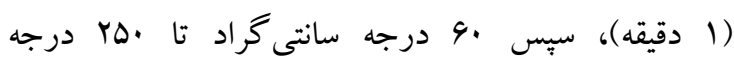
سانتى گراد (با روند افزايش ه درجه سانتى گراد در دقيقه)،

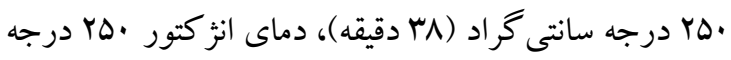

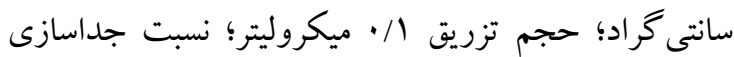
•ه:ا؛ كاز حامل هليوم با شدت جريان يك ميلىليتر در 10 دقيقه؛ بِتانسيل يونيزاسيون ·V ولت، جريان يونيزاسيون

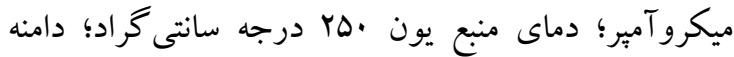
جرم هr تا 9ه4 ميكرو گرم تنظيم گرديد. طيف جرمى و شاخصهاى بازدارى (RI) هر جزء با نمونههاى معتبر و

\begin{tabular}{|c|c|c|c|}
\hline عصاره متانولى (درصد) & زمان بازدارى (دقيقه) & نام تر كيب & \\
\hline$\cdot / \Delta F$ & q/YOV & اوم-سينول & 1 \\
\hline $1 / \cdot 0$ & Q/IVY & بورئول ال & r \\
\hline $9 / 1$. & $1 . / N 1$. & r-فوران كربو كسالدئيد & r \\
\hline$\Delta Q / F F$ & $10 / 19 \mathrm{~V}$ & كومارين & F \\
\hline$I T / V$ & $r \cdot 19 \mathrm{NA}$ & V-متو كسى كومارين & $\Delta$ \\
\hline $1 / \mathrm{N}$ & rF/Or. & پِالميتيك اسيد & 4 \\
\hline
\end{tabular}
متون قبلى براى تعيين تركيبات مجزا مقايسه شد(19). مقادير

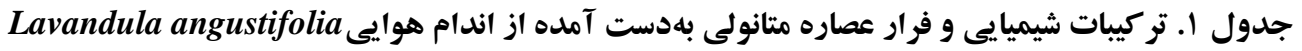




\begin{tabular}{|c|c|c|c|}
\hline $10 / Y r$ & $r \Delta / M M \Lambda$ & تريكو سان & V \\
\hline$r / \Delta \Delta$ & r9/9199 & E ويتامين & $\wedge$ \\
\hline
\end{tabular}

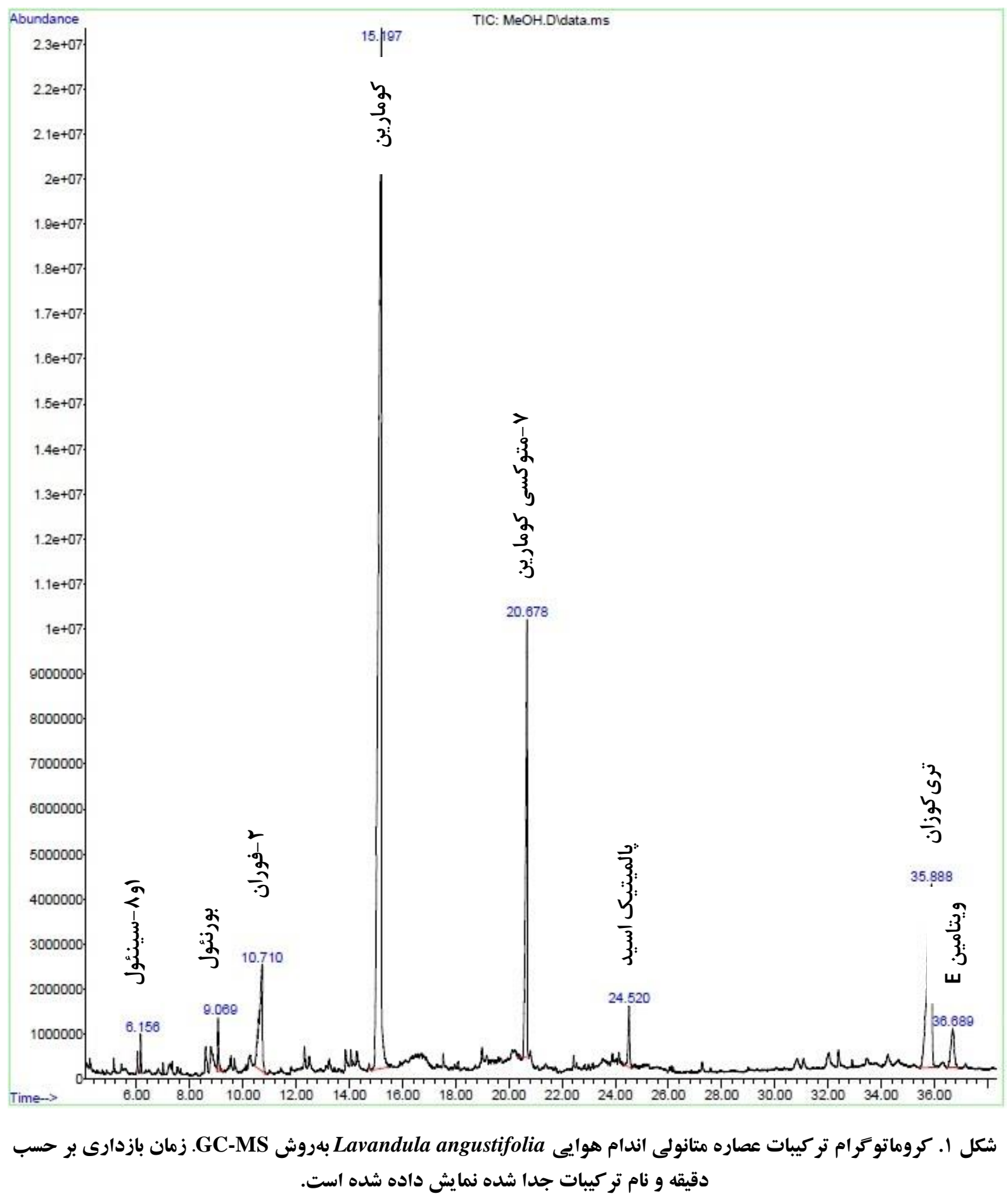

هبلم علمى دانشكاه علوه بِزشكى كردستان / دوره بيست و شش / فرودين و ارديبهشت م.ع|| 
اثر عصاره متانولى روى جرخه سلولى در ردههاى سلولى

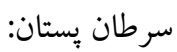
در ادامه، خصوصيات مهارى عصاره متانولى اسطوخودوس روى سلولهاى MCF-7 با بررسى اثر بر جرخه سلولى به

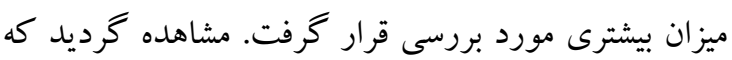

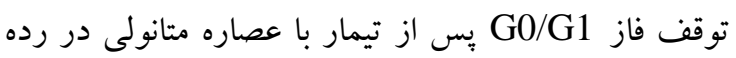

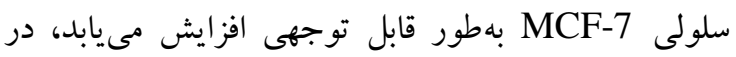
حاليكه فاز S در گروههاى كنترل منفى افزايش يافته است

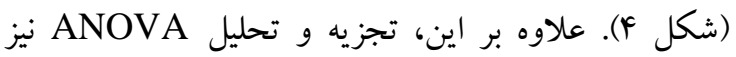
نشان داد كه غلظت . .0ه ميكرو گرم بر ميلى ليتر عصاره به طور قابل توجهى باعث افزايش جرخه سلولى در مرحله

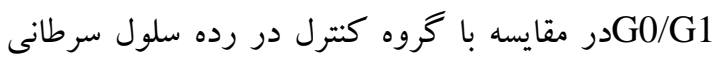

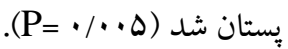

$$
\begin{aligned}
& \text { توانايى تشكيل كلنى: }
\end{aligned}
$$

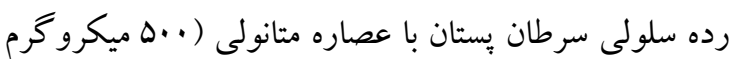

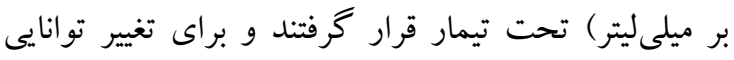

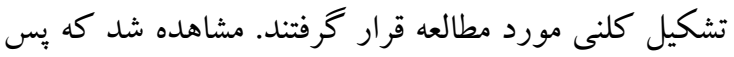

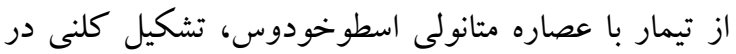

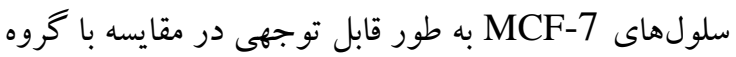
كنترل منفى، كاهش يافته است (شكل هاء).
اثرات عصارهى متانولى اسطوخودوس بر تكثير رده سلولى

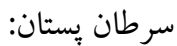
رده سلولى سرطان پِستان با غلظتهاى مختلف عصارهى

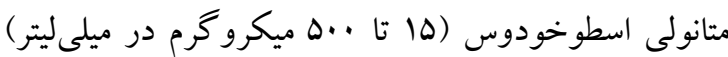

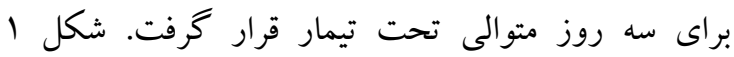
مورفولوزى اين رده سلولى را قبل و بعد از درمان با عصاره

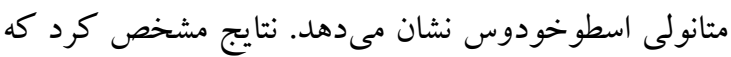
زنده ماندن ردههاى سلولى MCF-7 بِ از تيمار با عصاره

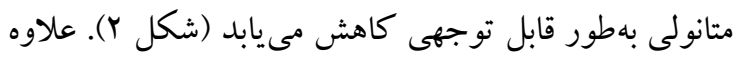
بر اين، دادههاى بهدست آمده بهوضوح نشان داد كه در هيج

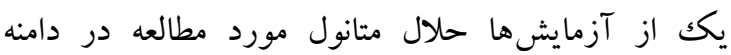
غلظتهاى به كار رفته اثر سميت سلولى ندارد. در ادامه غلظت مهار كننده رشد •ه درصدى سلولى (IC50) تعيين كرديد. بر اساس نتايج بهدست آمده

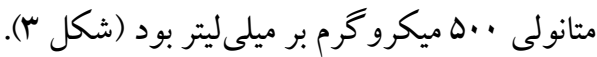
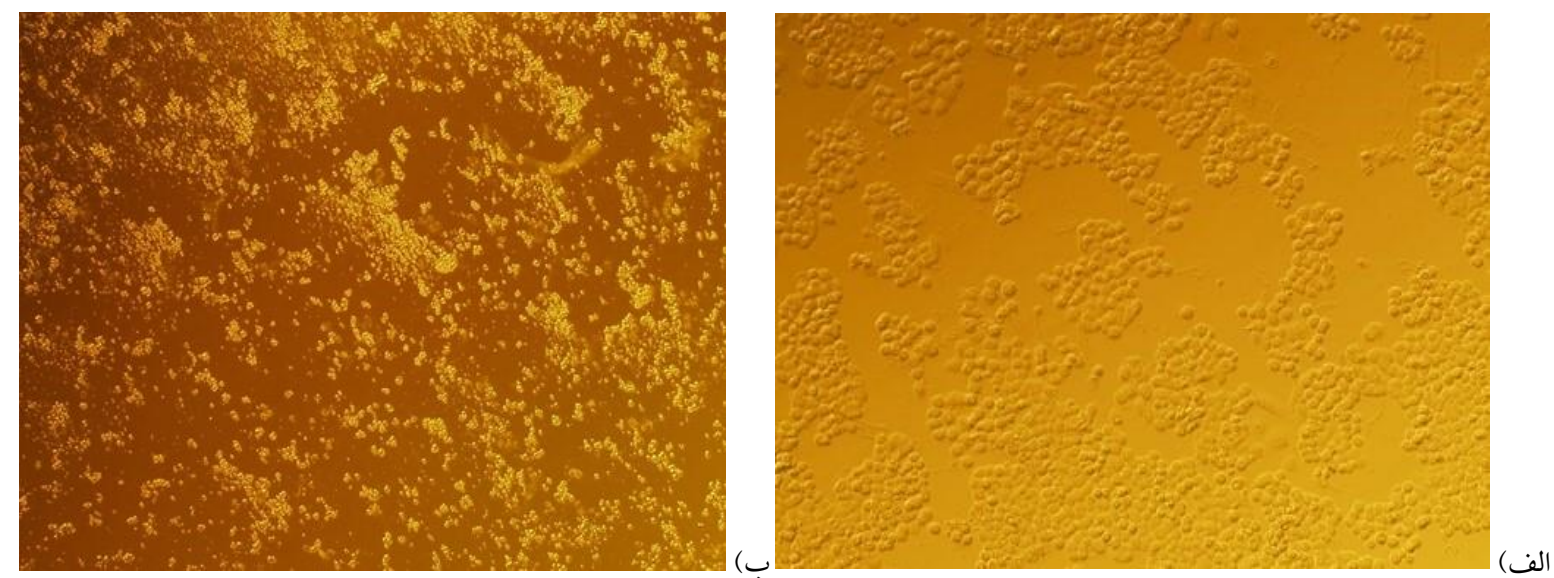

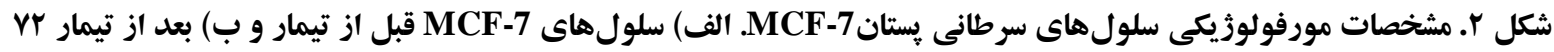

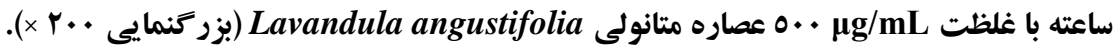




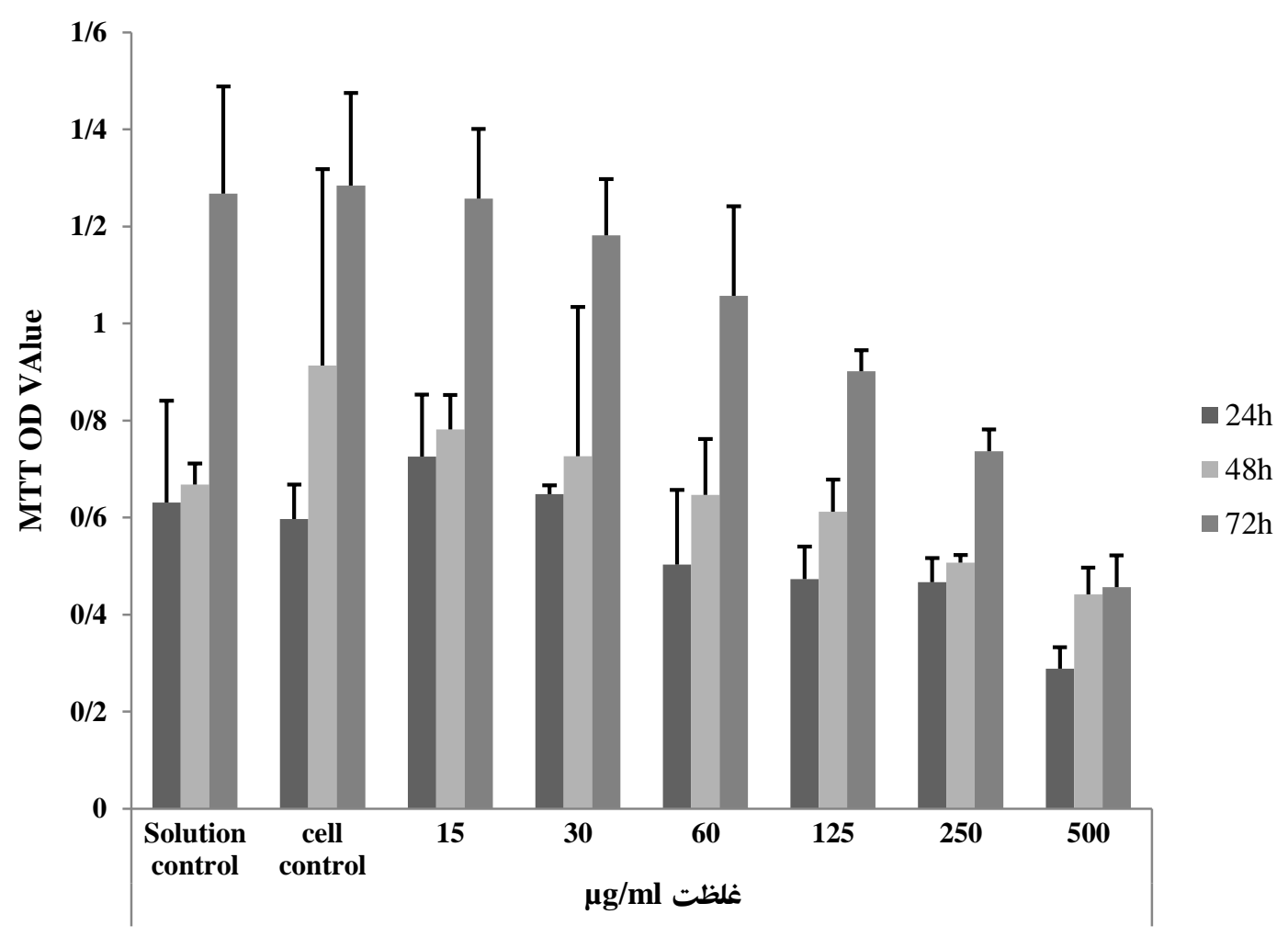

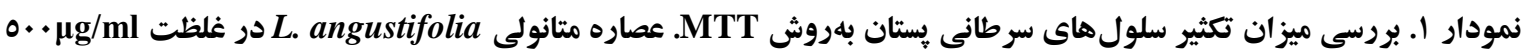

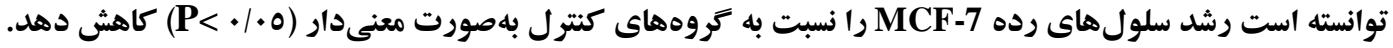

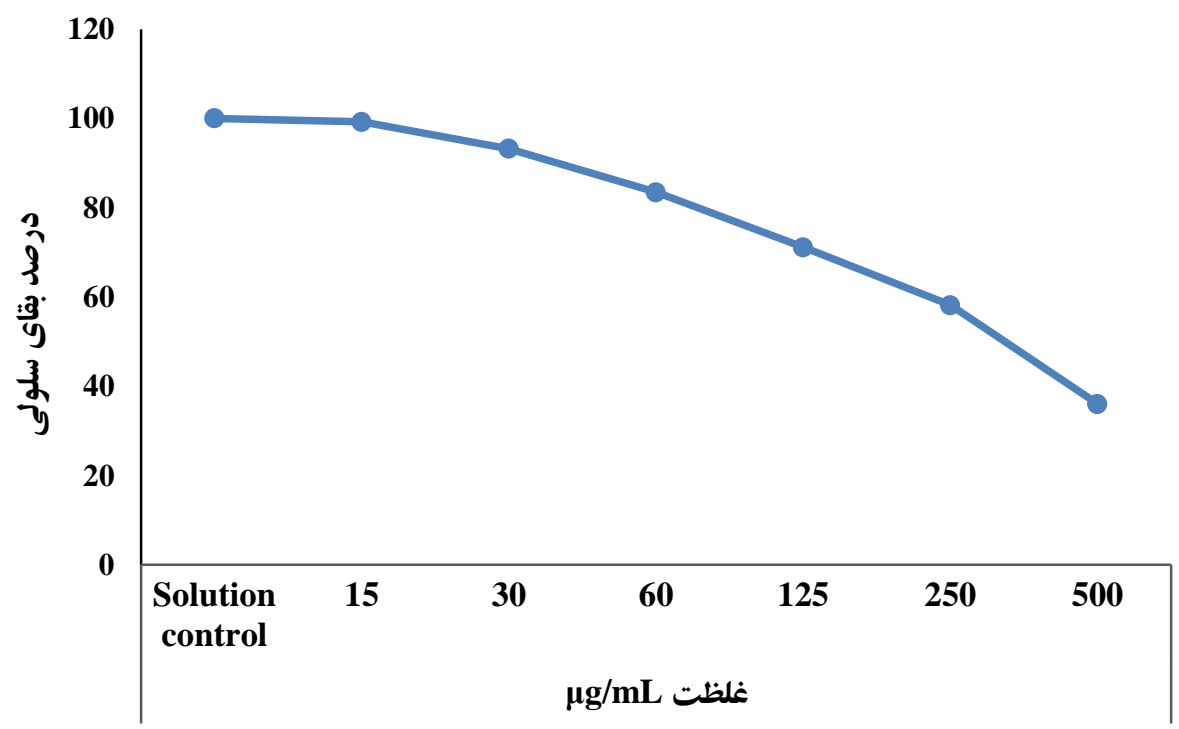

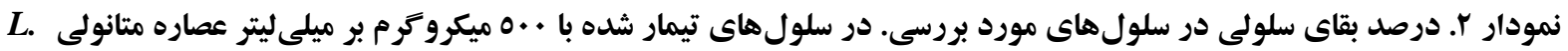
angustifolia 


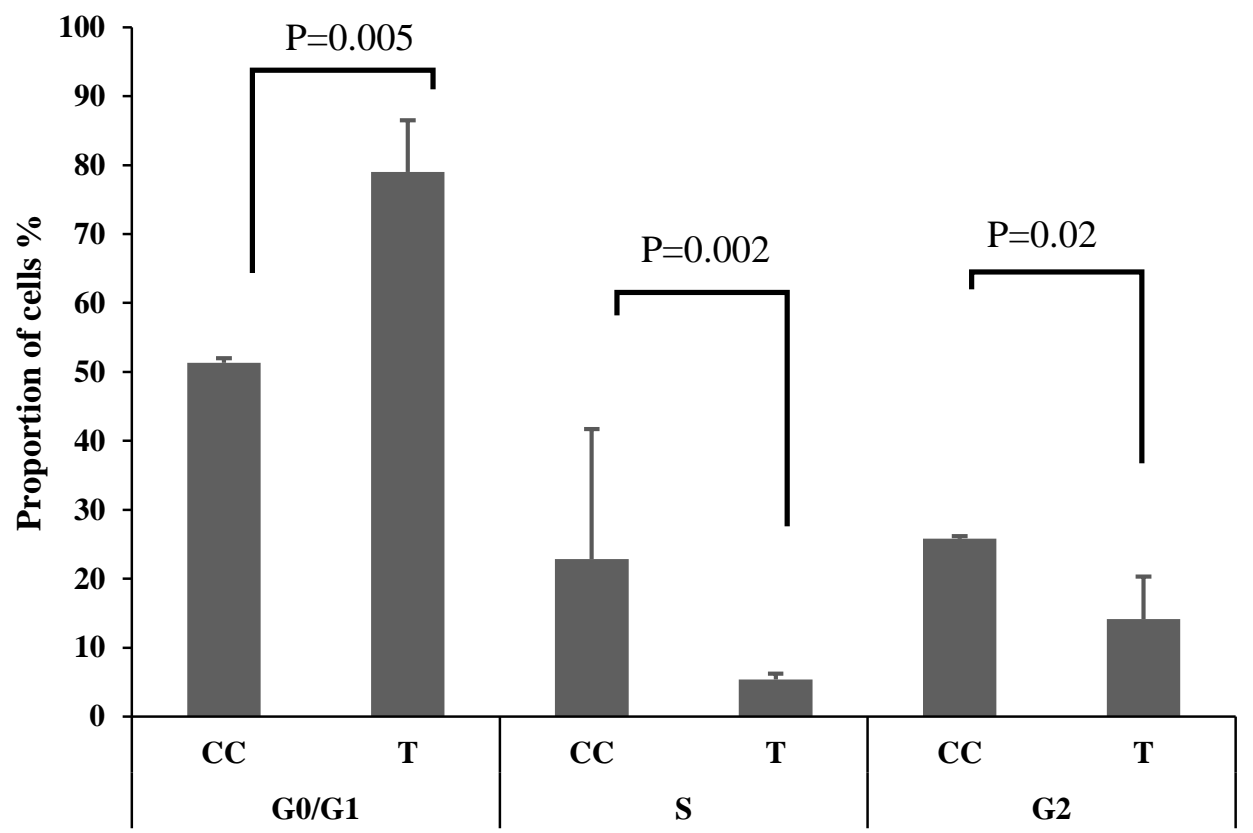

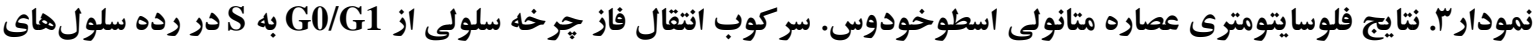

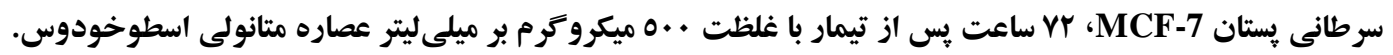
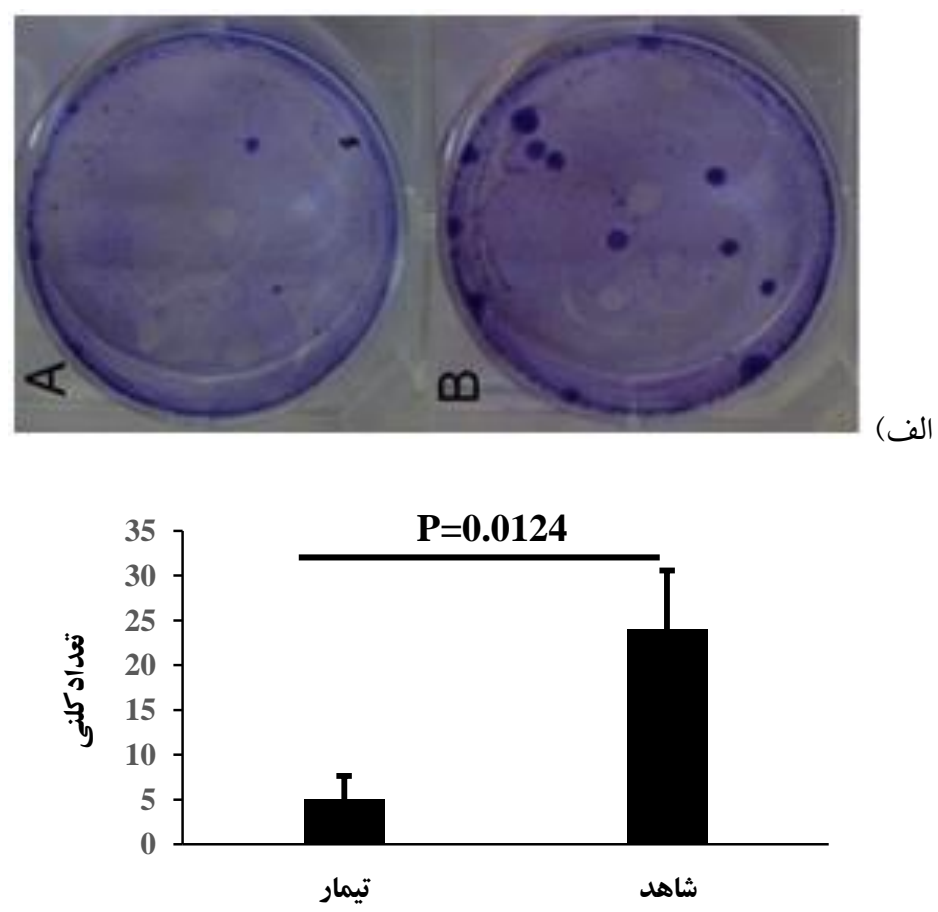

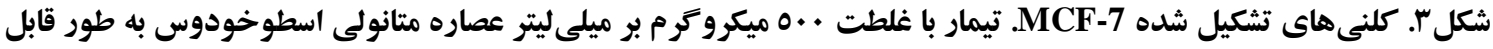

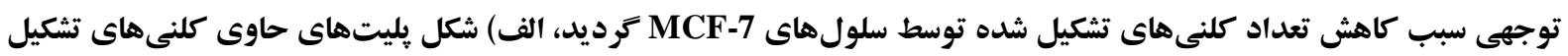

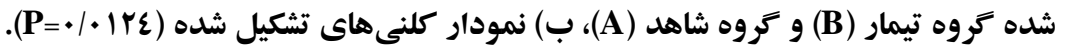


سلولى عصارههاى اتانولى، ان-هگز انى و روغنى بر روى هر دو نوع سلول سرطانى بود اخر جه عصاره آبى در هيج غلظتى توانايى از بين بردن سلولهاى سرطانى را نشان نداد.

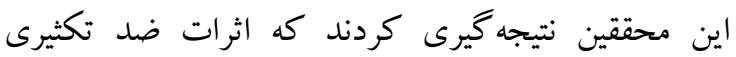

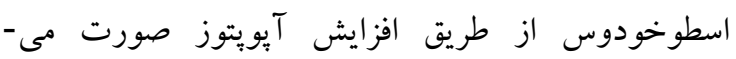

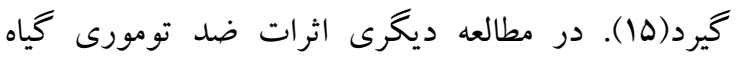
اسطوخودوس بر روى ردههاى سلولى سرطان بروستات شامل PC3 و DU145 و در هر دو محيط in vivo و و vitro

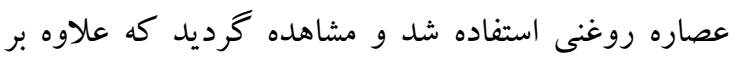

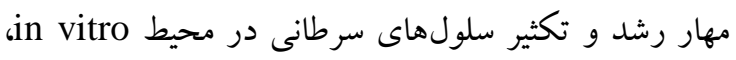

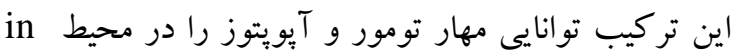

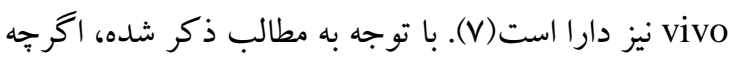

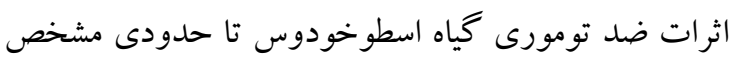
شده است، برخى از نتايج در زمينه اثرات عصارههاى مختلف آن تناقضاتى را نشان مىدهند. نتايج مطالعه حاضر نشان داد كه عصاره متانولى اسطوخودوس در غلظت ماره، دار خواص سيتوتو كسيك بر روى رده سلولى MCF-7 سرطان بِتان است. اخرجه مطالعه حاضر

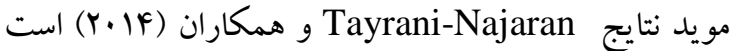
ولى تفاوتهايى نيز با آن دارد. در مطالعه حاضر برخلاف مطالعات بيشين از عصاره متانولى استفاده شد. بهعلاوه، بر اساس نتايج GC-MS، بيشترين تركيب موجود در عصاره Tayrani- متانولى، كومارين بود در حاليكه در مطالعه Najaran مقدار تركيبات به كادينول و فيتول اختصاص داشت(ها). همجنين دوز موثره در اين مطالعه بسيار هائين تر از دوز مورد استفاده براى عصاره متانولى بوده و IC50 بهدست آمده

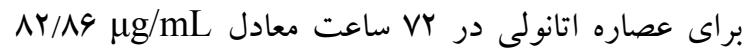
براى سلولهاى MCF-7 تعيين شده بود.

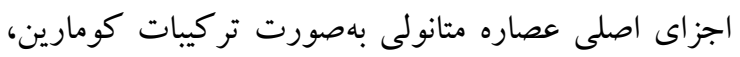
تريكوسان، V-متو كسى كومارين و Y-فوران كربو كسالدئيد

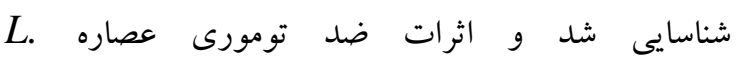
امروزه نقش طب مكمل بهعنوان ابزار كمكك درمانى مفيد همراه با درمانهاى اصلى و شناخته شده بسيار حائز اهميت است. در اين ميان طب گياهى يعنى استفاده از گياهان دارويى در درمان بيمارىهاى مختلف از جمله بيمارىهايى لئي با درمان سخت و گاهى لاعلاج مورد توجه قرار كرفته است. از جمله اين گياهان مىتوان به گياه اسطوخودوس اشاره كرد كه تر كيبات آن اثربخشى زيادى رادر مهار رشد سلولهاى سرطانى نشان داده است(ها). بر اساس مطالعات

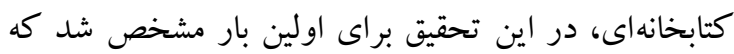
عصاره متانولى اسطوخودوس مىتواند رشد و تكثير سلول-

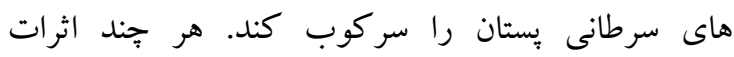

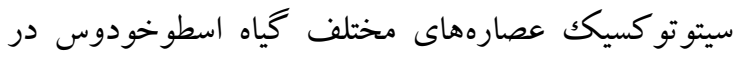
مطالعات ديخر نيز مورد بررسى قرار گرفته است. براى مثال،

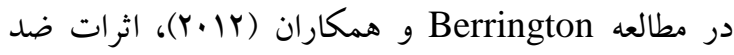
سرطانى عصاره استونى خندين گياه مختلف از جمله اسطوخودوس بر روى سلولهاى HELA مورد بررسى قرار

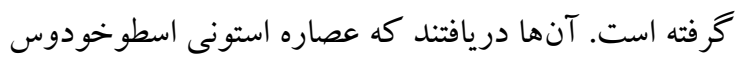
فاقد فعاليت ضد سرطانى بر روى اين دسته از سلولها مى -

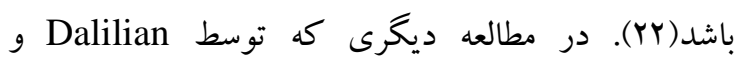

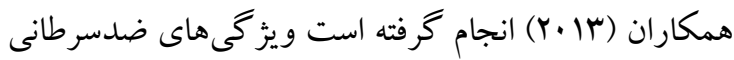
عصاره آبى گياه اسطوخودوس بر روى لنفوسيتهاى به به

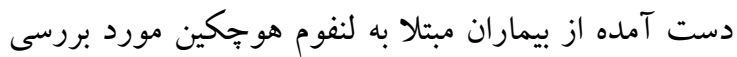

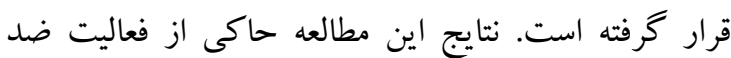
سرطانى عصاره آبى اسطوخودوس بر روى اين نوع از سلولها در غلظت Tayrani-Najaran بررسى اثرات سيتو تو كسيك سه عصاره مختلف از بخش - مهار هاى هوايى گياه اسطوخودوس بر روى سلولهاى HELA و MCF-7 انجام دادند(ه) ). در اين مطالعه، اثر عصاره هاى

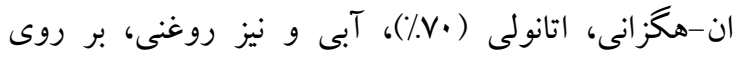

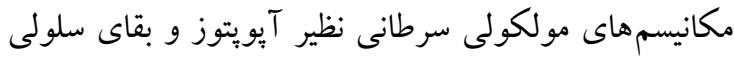

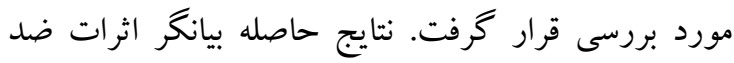




$$
\begin{aligned}
& \text { و اين اثر از طريق القاى مهار رشد و همجنين مهار خرخه } \\
& \text { سلولى در فاز G0/G1 اعمال مىشود؛ بنابراين، استفاده از } \\
& \text { عصارمى اسطوخودوس مى تو اند بهعنوان يك داروى مكمل فيل } \\
& \text { بالقوه در مطالعات بعدى در نظر گرفته شود. }
\end{aligned}
$$

$$
\text { تشكر و قدردانى }
$$

اين طرح بهصورت مشترك توسط دانشگاه آزاد اسلامى فدردابى

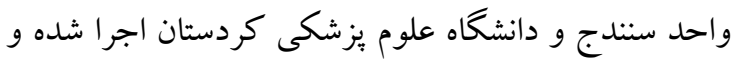

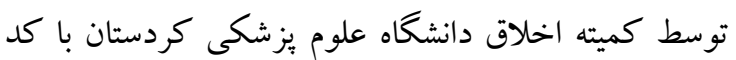
اخلاق (IR.MUK.REC.1397/98) مورد تائيد قرار

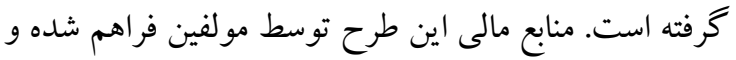

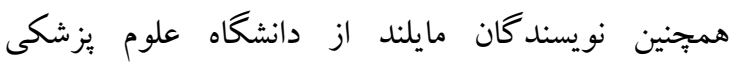

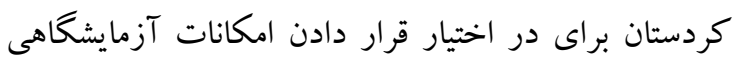

$$
\text { تشكر و قدردانى نمايند. }
$$

angustifolia به وجود اين تركيبات باشد. علاوه بر اين، نتايج فلوسايتومترى افزايش توقف جرخه سلولى را پِس از در معرض قرار دادن ردههاى سلولى سرطان بِّتان با عصاره

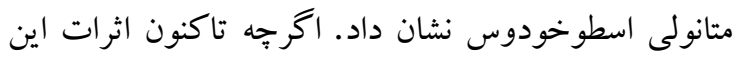
عصاره روى جرخه سلولى در سرطان بستان بررسى نشده است، با اين وجود نتايج بررسىها بر روى ساير سرطانها

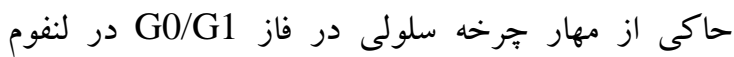

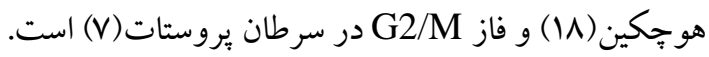

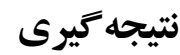

در مجموع، نتايج مطالعه حاضر نشان داد كه عصاره متانولى

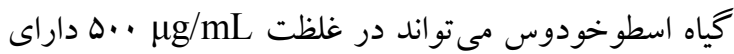
خو اص ضد تومورى بر عليه رده سلولهاى MCF-7 سرطان

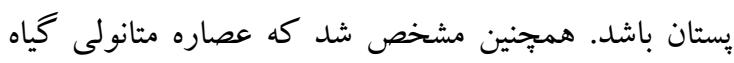
اسطوخودوس باعث مهار تكثير سلولهاى MCF-7 مىشود

منابع

1. Taghavi A, Fazeli Z, Vahedi M, Baghestani AR, Pourhoseingholi A, Barzegar F, et al. Increased trend of breast cancer mortality in Iran. Asian Pac J Cancer Prev. 2012; 13(1):367-70.

2. Sharifian A, Pourhoseingholi MA, Emadedin M, Rostami Nejad M, Ashtari S, Hajizadeh N, et al. Burden of Breast Cancer in Iranian Women is Increasing. Asian Pac J Cancer Prev. 2015; 6(12):504952.

3. Odle TG. Adverse effects of breast cancer treatment. Radiol Technol. 2014; Jan-Feb;85(3):297M319M; quiz 20M-23M.

4. Lovelace DL, McDaniel LR, Golden D. Long-Term Effects of Breast Cancer Surgery, Treatment, and Survivor Care. J Midwifery Womens Health. 2019;64(6):713-24.

5. Lin بSR, Chang CH, Hsu CF, Tsai MJ, Cheng H, Leong MK, et al. Natural compounds as potential adjuvants to cancer therapy: preclinical evidence. Br J Pharmacol. 2020; 177(6):1409-23.

6. Wang S, Lin H, Cong W. Chinese Medicines Improve Perimenopausal Symptoms Induced by Surgery, Chemoradiotherapy, or Endocrine Treatment for Breast Cancer. Front Pharmacol. 2019; $10: 174$

7. Zhu L, Li L, Li Y, Wang J, Wang Q. Chinese Herbal Medicine as an Adjunctive Therapy for Breast Cancer: A Systematic Review and Meta-Analysis. Evid Based Complement Alternat Med. 2016;9469276.

8. Lesage-Meessen L, Bou M, Sigoillot JC, Faulds CB, Lomascolo A. Essential oils and distilled straws of lavender and lavandin: a review of current use and potential application in white biotechnology. Appl Microbiol Biotechnol. 2015;99(8):3375-85. 
9. Giovannini D, Gismondi A, Basso A, Canuti L, Braglia R, Canini A, et al. Lavandula angustifolia Mill. Essential Oil Exerts Antibacterial and Anti-Inflammatory Effect in Macrophage Mediated Immune Response to Staphylococcus aureus. Immunol Invest. 2016; 45(1):11-28.

10. Carrasco A, Martinez-Gutierrez R, Tomas V, Tudela J. Lavandula angustifolia and Lavandula latifolia Essential Oils from Spain: Aromatic Profile and Bioactivities. Planta Med. 2016; 82(1-2):16370.

11. Nasiri A, Mahmodi MA. Aromatherapy massage with lavender essential oil and the prevention of disability in ADL in patients with osteoarthritis of the knee: A randomized controlled clinical trial. Complement Ther Clin Pract. 2018; 30:116-21.

12. Ayaz M, Sadiq A, Junaid M, Ullah F, Subhan F, Ahmed J. Neuroprotective and Anti-Aging Potentials of Essential Oils from Aromatic and Medicinal Plants. Front Aging Neurosci. 2017; 9:168.

13. Mahady GB, Pendland SL, Stoia A, Hamill FA, Fabricant D, Dietz BM, et al. In vitro susceptibility of Helicobacter pylori to botanical extracts used traditionally for the treatment of gastrointestinal disorders. Phytother Res. 2005; 19(11):988-91.

14. Zhao Y, Chen R, Wang Y, Qing C, Wang W, Yang Y.In Vitro and In Vivo Efficacy Studies of Lavender angustifolia Essential Oil and Its Active Constituents on the Proliferation of Human Prostate Cancer. Integr Cancer Ther. 2017; 16(2):215-26.

15. Tayarani-Najaran Z, Amiri A, Karimi G, Emami SA, Asili J, Mousavi SH. Comparative studies of cytotoxic and apoptotic properties of different extracts and the essential oil of Lavandula angustifolia on malignant and normal cells. Nutr Cancer. 2014; 66(3):424-34.

16. Prusinowska R, Śmigielski KB. Composition, biological properties and therapeutic effects of lavender (Lavandula angustifolia L). A review. Herba polonica. 2014; 60(2):56-66.

17. Soheili M, Salami M. Lavandula angustifolia biological characteristics: An in vitro study. J Cell Physiol. 2019;234(9):16424-30.

18. Dalilan S, Rezaei-Tavirani M, Nabiuni M, Heidari-Keshel S, Zamanian Azodi M, Zali H. Aqueous Extract of Lavender angustifolia Inhibits Lymphocytes Proliferation of Hodgkin's Lymphoma Patients. Iran J Cancer Prev. 2013; 6(4):201-8.

19. Buyukokuroglu ME, Gepdiremen A, Hacimuftuoglu A, Oktay M. The effects of aqueous extract of Lavandula angustifolia flowers in glutamate-induced neurotoxicity of cerebellar granular cell culture of rat pups. J Ethnopharmacol. 2003; 84(1):91-4.

20. Menbari MN, Rahimi K, Ahmadi A, Elyasi A, Darvishi N, Hosseini V, et al. MiR-216b-5p inhibits cell proliferation in human breast cancer by down-regulating HDAC8 expression. Life Sci. 2019; $15 ; 237: 116945$.

21. Menbari MN, Rahimi K, Ahmadi A, Mohammadi-Yeganeh S, Elyasi A, Darvishi N, et al. miR483-3p suppresses the proliferation and progression of human triple negative breast cancer cells by targeting the HDAC8>oncogene. J Cell Physiol. 2020; 235(3):2631-42.

22. Berrington D, Lall N, Anticancer Activity Of certain Herbs and Spices on the cervical epithelial carcinoma (Hela) cell line.Europe PMC.2012; 564927. 